\title{
The heterogeneity of bovine growth hormone
}

\author{
Extraction from the pituitary of components with different biological and immunological properties \\ Ian C. HART, Laura A. BLAKE, Patricia M. E. CHADWICK, Gerald A. PAYNE and \\ Alan D. SIMMONDS \\ National Institute for Research in Dairying, Shinfield, Reading, Berks. RG2 9AT, U.K.
}

(Received 12 May 1983/Accepted 15 November 1983)

\begin{abstract}
Bovine growth hormone (somatotropin) was extracted from anterior pituitaries and fractionated into four protein peaks (A-D) by chromatography on DEAE-Sephacel. Analysis by high-pressure liquid chromatography and sodium dodecyl sulphate/polyacrylamide-gel electrophoresis indicated that the homogeneity of the material increased from fraction A through to $D$. The properties of the fractions were examined in the following manner: immunological activity (radioimmunoassays for ruminant growth hormone and prolactin); growth-promoting activity (rat tibia test); lipolytic activity (release of glycerol from rat epididymal fat in the presence of dexamethasone); diabetogenic activity (rate of glucose transport in epididymal fat of hypophysectomized rats and intravenous insulin-tolerance tests in goats). None of the fractions contained immunoreactive prolactin and all were equally lipolytic. Although fraction A contained a small quantity of immunoreactive growth hormone it had no growth-promoting or diabetogenic activities. Both fractions $\mathbf{B}$ and $\mathbf{C}$ were diabetogenic and contained high concentrations of immunoreactive growth hormone, consistent with their growth-promoting activity. Although the growth-promoting activity of fraction $D$ was higher than that of the other three fractions, it was not diabetogenic and was only weakly immunoreactive. These results for bovine growth hormone support the contention that growth hormone, as commonly extracted, is a mixture of different molecular forms and that these different metabolic properties of the hormone might be explained in terms of this heterogeneity.
\end{abstract}

It has been known for decades that the subcutaneous injection of bovine $\mathrm{GH}$, of variable quality, increases milk yield in cows, goats and sheep (Cowie et al., 1980). However, it is still not known how the hormone exerts its galactopoietic effect. One possibility is that the hormone stimulates lipolysis and/or partitions nutrients away from tissue deposition, thereby increasing the supply of triacylglycerols and glucose to the mammary gland for the synthesis of additional milk (Hart et al., 1978; Hart, 1983). Extensive work with human GH has established that the hormone, as commonly prepared, is not a single molecular entity but a mixture of variants often differing in their biological and immunological activities. By the use of anion-exchange and gelchromatographic techniques human $\mathrm{GH}$ has been prepared with neither diabetogenic nor lipolytic activities (Lewis et al., 1980; Frigeri, 1980).

\footnotetext{
Abbreviation used: GH, growth hormone (somatotropin).
}

Preliminary investigations with the bovine hormone suggested that it might be similarly heterogeneous and that differences in biological activity might be expected (Manchester \& Wallis, 1963; Swislocki et al., 1971; Assa \& Laron, 1977). None of these studies included an examination of the immunological and diabetogenic activities of the hormone.

The present work describes the fractionation of a crude bovine anterior-pituitary extract into preparations that vary in their immunological and biological (growth-promoting, lipolytic, diabetogenic) properties, with a view to eventually testing the effects of these materials on aspects of intermediary metabolism and milk yield in ruminants.

\section{Materials and methods \\ Extraction and fractionation}

The extraction and fractionation of the pituitaries was based on the method of Wallis \& Dixon 
(1966) for the chromatographic preparation of bovine $\mathrm{GH}$.

Approx. $100 \mathrm{~g}$ of frozen bovine anterior pituitaries was partially thawed, homogenized with $300 \mathrm{ml}$ of buffer $\left(0.25 \mathrm{M}-\mathrm{NaCl} / 6.5 \mathrm{mM}-\mathrm{Na}_{2} \mathrm{~B}_{4} \mathrm{O}_{7} /\right.$ $5.5 \mathrm{~mm}-\mathrm{HCl}$ buffer, $\mathrm{pH} 8.7)$ and stirred for $3 \mathrm{~h}$ in an ice bath. The extract was centrifuged $(10000 \mathrm{~g}$ for $30 \mathrm{~min}$ at $4^{\circ} \mathrm{C}$ ) and the supernatant retained. The residue was ground with sand, re-extracted for a further $1 \mathrm{~h}$ in $200 \mathrm{ml}$ of the same buffer and centrifuged as before. The combined supernatants were then centrifuged $\left(15000 \mathrm{~g}\right.$ for $30 \mathrm{~min}$ at $\left.4^{\circ} \mathrm{C}\right)$, dialysed against six changes of borate $/ \mathrm{HCl}$ buffer (6.5 mM- $\mathrm{Na}_{2} \mathrm{~B}_{4} \mathrm{O}_{7} / 5.5 \mathrm{mM}-\mathrm{HCl}$ buffer, $\left.\mathrm{pH} 8.7\right)$ and frozen overnight.

After centrifugation $\left(30000 \mathrm{~g}\right.$ for $30 \mathrm{~min}$ at $4^{\circ} \mathrm{C}$ ) the thawed extract was chromatographed on a column $\left(50 \mathrm{~cm} \times 19.6 \mathrm{~cm}^{2}\right)$ of DEAE-Sephacel (Pharmacia Fine Chemicals) equilibrated with borate $/ \mathrm{HCl}$ buffer and maintained at $4^{\circ} \mathrm{C}$. Elution was continued with this buffer at a flow rate of $110 \mathrm{ml} / \mathrm{h}$, and $17 \mathrm{ml}$ fractions were collected. Measurements of the absorbance at $280 \mathrm{~nm}$ showed four protein peaks (fractions A-D; Fig. 1). The contents of the tubes within these peaks were combined, dialysed against three changes of distilled water and freeze-dried.

\section{Sodium dodecyl sulphate/polyacrylamide-gel electrophoresis}

The method was based on the procedure of Shapiro et al. (1967) as modified by Weber \& Osborn (1969), and used a $10 \mathrm{~mm}$-imidazole $/ \mathrm{HCl}$ buffer, $\mathrm{pH}$ 7.0, instead of the phosphate system, to shorten the separation time.

Electrophoresis was carried out on a horizontal thin-layer gel (10\% acrylamide) in an LKB 2117 Multiphor apparatus with controlled cooling $\left(5^{\circ} \mathrm{C}\right)$ at a constant current of $70 \mathrm{~mA}$ and a voltage of $0.8 \mathrm{~V}$ for $4 \mathrm{~h}$. Approx. $20 \mu \mathrm{g}$ of protein was applied to each well, and cross-linked haemoglobin $\left(M_{\mathrm{r}}\right.$ 16000-64000; Sigma Chemical Co.) was run as a standard. Gels were stained for $15 \mathrm{~h}$ with $0.1 \%$ Coomassie Blue R250.

\section{High-pressure liquid chromatography}

High-pressure liquid chromatography was performed with an Altex $100 \mathrm{~A}$ solvent-delivery system coupled to a Pye PV4020 ultraviolet detector. Separation was carried out on an Ultrapac column (TSK G $3000 \mathrm{SW} ; 7.5 \mathrm{~mm} \times 600 \mathrm{~mm}$; LKB Instruments), which was eluted with $0.1 \mathrm{M}$ potassium phosphate buffer, $\mathrm{pH} 7.5$, at a flow rate of $0.75 \mathrm{ml} / \mathrm{min}$. $M_{\mathrm{r}}$ calibration was achieved with a Dalton Mk. VI protein solution (Sigma Chemical Co.). Material $(75 \mu \mathrm{g})$ was dissolved in dilute $\mathrm{NaOH}, \mathrm{pH} 9.6(300 \mu \mathrm{l})$, and $20 \mu \mathrm{l}$ samples were used for each analysis with detection at $210 \mathrm{~nm}$.

\section{Radioimmunoassay}

The immunological activity of the material was assessed by using radioimmunoassays specific for bovine prolactin (Hart, 1972) or GH (Hart et al., 1975), with modifications described by Tindal $e t$. al. (1982).

\section{Growth-promoting activity}

Growth-promoting activity was measured by the rat tibia test (Greenspan et al., 1949) as modified by $\mathrm{Li}$ (1977), and employed bovine GH (NIH-GHB15; 0.69 units $/ \mathrm{mg}$ ) as the standard preparation. Male Sprague-Dawley rats were obtained from Olac (Bicester, Oxon, U.K.) and hypophysectomized by the sterotaxic transauricular route (Gay, 1967) at approx. $120 \mathrm{~g}$ body wt.

\section{Lipolytic activity}

The lipolytic activity was evaluated in vitro by using epididymal fat-pads from Sprague-Dawley rats $(150-180 \mathrm{~g})$. The rats were starved for $48 \mathrm{~h}$ before being killed by cervical dislocation. Both rat pads (approx. $250 \mathrm{mg}$ each) were removed, rinsed in $0.9 \% \mathrm{NaCl}$ at $37^{\circ} \mathrm{C}$, blotted and weighed and each was placed in separate siliconized conical flasks (25 ml) containing $1 \mathrm{ml}$ of KRB buffer (Krebs-Ringer bicarbonate buffer pH 7.4; Paul, 1965) containing bovine serum albumin (fraction V, fatty acid-free; Sigma Chemical Co. $)(40 \mathrm{mg} / \mathrm{ml})$ and dexamethasone $(0.22 \mu \mathrm{g} / \mathrm{ml})$. The material to be tested was dissolved in KRB buffer containing bovine serum albumin, and the addition of $0.1 \mathrm{ml}$ to the experimental flask gave a final concentration of $0.1 \mathrm{mg} / \mathrm{ml}$ of medium. The other flask was used as a control $(0.1 \mathrm{ml}, \mathrm{KRB}$ buffer containing bovine serum albumin), and both flasks were incubated for $4 \mathrm{~h}$ in a shaking water bath $\left(37^{\circ} \mathrm{C}\right)$ in an atmosphere of $\mathrm{O}_{2} / \mathrm{CO}_{2}(19: 1)$. Samples of medium for glycerol analysis were removed from all flasks both before and after incubation (Boehringer, fully enzymic method). Each test was replicated five times, and significance was determined by the Student's $t$-test for paired observations.

\section{Diabetogenic activity}

In the context of this study diabetogenic activity is defined as the ability of the test material $(a)$ to decrease the rate of glucose transport in adipose tissue taken from hypophysectomized rats and $(b)$ to impair insulin-sensitivity in goats as measured by the insulin-tolerance test.

(a) The effect of the material on glucose transport was measured by using a method similar to that of Zapf et al. (1981), with the rate of efflux of non-metabolizable glucose from adipose tissue being used as an indication of changes in glucose 
transport (Clausen, 1969). Male Sprague-Dawley rats (body wt. $100 \mathrm{~g}$ ) were hypophysectomized and used only if their body weight did not increase by more than $7 \mathrm{~g}$ in 3 weeks. Each rat received $0.9 \%$ $\mathrm{NaCl}$ (control) or the test material dissolved in $0.9 \% \mathrm{NaCl}(100 \mu \mathrm{g} / 0.2 \mathrm{ml}$ per day, subcutaneously) for 3 days before being killed by cervical dislocation. Both epididymal fat-pads (approx. $150 \mathrm{mg}$ ) were incubated for $70 \mathrm{~min}$ at $37^{\circ} \mathrm{C}$ in a siliconized scintillation vial $(20 \mathrm{ml})$ containing $3 \mathrm{ml}$ of KRB buffer containing bovine serum albumin $(15 \mathrm{mg} / \mathrm{ml}), \mathrm{pH} 7.4$, and $30 \mathrm{~mm}-3-O-\left[\mathrm{U}-{ }^{14} \mathrm{C}\right] \mathrm{methyl}-$ glucose $(6 \mu \mathrm{Ci}$; Amersham International). After preincubation the pads were rinsed over gauze ( $8 \mathrm{ml}$ of KRB buffer containing bovine serum albumin at $37^{\circ} \mathrm{C}$ ), blotted and re-immersed in $3 \mathrm{ml}$ of fresh KRB buffer containing bovine serum albumin and unlabelled 30mM-3-O-methylglucose (Sigma Chemical Co.). After $10 \mathrm{~min}$ the pads were separated from the medium, rinsed and blotted as before, and transferred to another $3 \mathrm{ml}$ of KRB buffer containing bovine serum albumin and 3-Omethylglucose. Samples $(0.1 \mathrm{ml})$ of incubation medium were taken from the vials at $5,10,20,30$ and $40 \mathrm{~min}$ intervals, pipetted into $5 \mathrm{ml}$ of Instagel (Packard Instrument Co.) and their radioactivities counted in a liquid-scintillation counter. Immediately after the 40 min sample had been taken, the fat-pads were separated from the medium, rinsed with $20 \mathrm{ml}$ of $0.9 \% \mathrm{NaCl}$ at $37^{\circ} \mathrm{C}$, blotted and homogenized in $1 \mathrm{ml}$ of $1 \mathrm{M}-\mathrm{NaOH}$. The fat was digested by heating for $30 \mathrm{~min}$ in a boilingwater bath, cooled in ice, neutralized with $1 \mathrm{ml}$ of $1 \mathrm{M}-\mathrm{HCl}$ and centrifuged $\left(2000 \mathrm{~g}\right.$ for $30 \mathrm{~min}$ at $\left.4^{\circ} \mathrm{C}\right)$. A sample $(0.5 \mathrm{ml})$ of infranatant was removed with a syringe, added to $5 \mathrm{ml}$ of Instagel and its radioactivity counted.

All values were expressed as the ratio of the radioactivities present in the incubation medium at time $t$ (c.p.m.t) to the total radioactivity

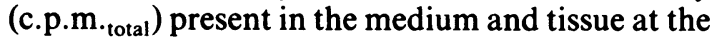
end of the incubation. This ratio was subtracted from unity (1.0) such that at every time interval this difference reflects the fraction of the total radioactivity released into the medium.

(b) Intravenous insulin-tolerance tests were carried out in castrated male goats (body wt. approx. $40 \mathrm{~kg}$ ) that had been pretreated with the test material dissolved in $0.9 \% \mathrm{NaCl}(0.15 \mathrm{mg} / \mathrm{kg}$ injected subcutaneously twice daily for 3 days). The goats, which had previously been fed ad libitum, were starved for $19 \mathrm{~h}$ before each insulintolerance test. On the morning of the test three or four blood samples $(5 \mathrm{ml})$ were taken at $10-15 \mathrm{~min}$ intervals from a jugular catheter, inserted at least $24 \mathrm{~h}$ previously and the stability of the pre-insulin glucose values was immediately established with a HypoCount blood glucose monitor. Bovine insulin
$(0.08$ unit $/ \mathrm{kg}$ in $2 \mathrm{ml}$ of sterile $0.9 \% \mathrm{NaCl})$ was then injected via the catheter followed by $2 \mathrm{ml}$ of $0.9 \%$ $\mathrm{NaCl}$. Further blood samples were taken at $10 \mathrm{~min}$ intervals for $30 \mathrm{~min}$ after the insulin injection, and the plasma was analysed for glucose with a Chemlab continuous-flow analyser. Each test of experimental material was preceded by a control insulin-tolerance test in which the goats had been injected for 3 days with sterile $0.9 \% \mathrm{NaCl}$.

\section{Results}

\section{Extraction and fractionation}

Fig. 1 shows the elution pattern obtained after fractionation of the anterior-pituitary extract on DEAE-Sephacel. On occasions the separation of peaks $C$ and $D$ was less distinct, but they were still readily discernible.

\section{Sodium dodecyl sulphate/polyacrylamide-gel electrophoresis}

Sodium dodecyl sulphate/polyacrylamide-gel electrophoresis in the presence of 2-mercaptoethanol revealed a single component in five preparations of fraction $\mathrm{D}$ and an additional band at $M_{\mathrm{r}} 44000$ in two further preparations. There were three components in fractions $\mathrm{C}$ and $\mathrm{D}$, eight components in fraction $\mathrm{A}$ and four components in a crude preparation of bovine GH (bGH5) that was prepared by the method of Ellis (1961) and included for comparison. The estimated $M_{\mathrm{r}}$ values of these components are shown in Fig. 2. The

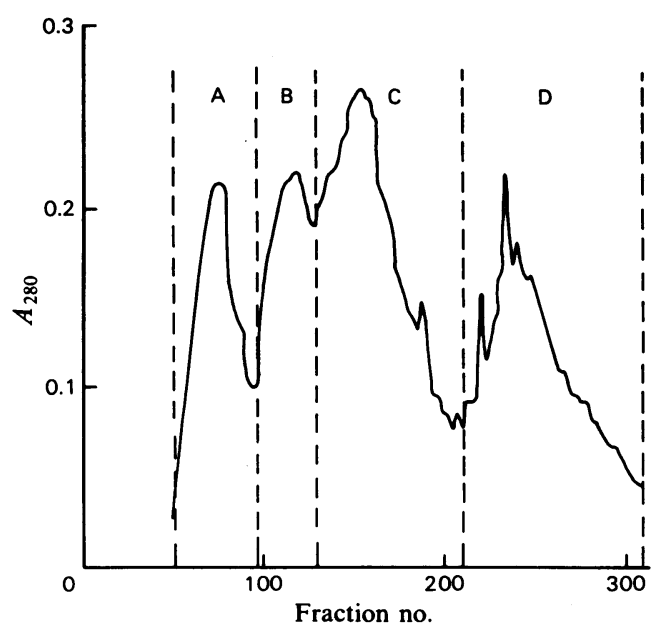

Fig. 1. Elution profile of bovine anterior-pituitary extract on DEAE-Sephacel

The column $\left(50 \mathrm{~cm} \times 19.6 \mathrm{~cm}^{2} ; 4^{\circ} \mathrm{C}\right)$ was eluted with $6.5 \mathrm{mM}-\mathrm{Na}_{2} \mathrm{~B}_{4} \mathrm{O}_{7} / 5.5 \mathrm{~mm}-\mathrm{HCl}$ buffer, $\mathrm{pH} 8.7$, at a flow rate of $110 \mathrm{ml} / \mathrm{h}, 17 \mathrm{ml}$ fractions being collected. 


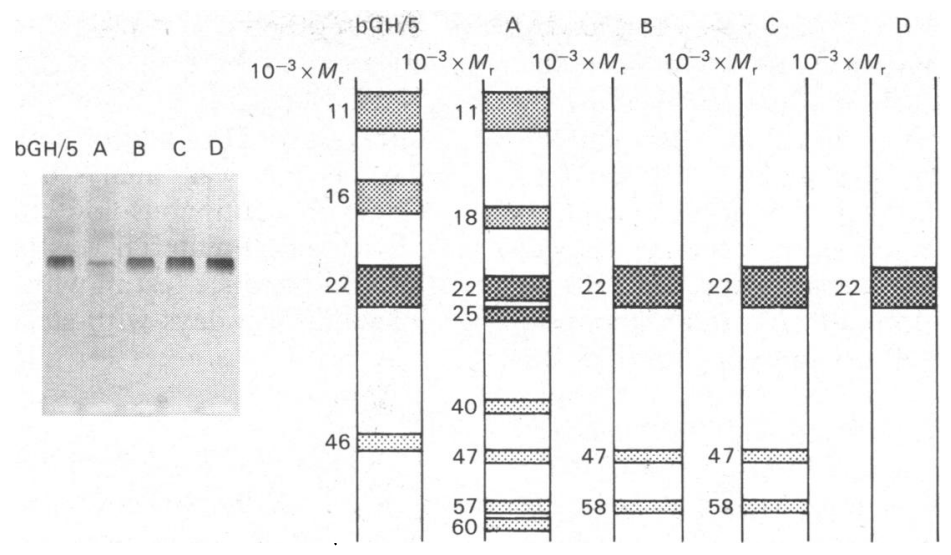

Fig. 2. Approximate $M_{r}$ values obtained by sodium dodecyl sulphate/polyacrylamide-gel electrophoresis Sodium dodecyl sulphate/polyacrylamide-gel electrophoresis was carried out in $10 \mathrm{mM}$-imidazole $/ \mathrm{HCl}$ buffer, $\mathrm{pH} 7.0$, at $70 \mathrm{~mA}$ and $0.8 \mathrm{~V}$ for $4 \mathrm{~h}$. A diagram of the electrophoretograms is shown as well as the photograph on which it is based.

$22000-M_{\mathrm{r}}$ band was present to a greater or lesser extent in all of the fractions.

\section{High-pressure liquid chromatography}

The results of the high-pressure liquidchromatographic analysis are illustrated in Fig. 3; the lowest $M_{\mathrm{r}}$ capable of resolution with this system is 20000 . Although high-pressure liquid chromatography and sodium dodecyl sulphate/ polyacrylamide-gel electrophoresis revealed similar degrees of heterogeneity for the four fractions, there was disparity between the $M_{\mathrm{r}}$ values of the individual components. Fraction A was the most heterogeneous, having several components with $M_{\mathrm{r}}$ values ranging from less than 20000 to 94000 . As with the sodium dodecyl sulphate/polyacrylamide-gel-electrophoresis data, fractions B and C appeared to be identical, with four components at $M_{\mathrm{r}}<20000,22000,38000$ and 96000 . Fraction D exhibited only one peak, at $M_{\mathrm{r}} 22000$. It is worth noting that the two preparations of fraction $D$ that exhibited an additional band with sodium dodecyl sulphate/polyacrylamide-gel electrophoresis were found with high-pressure liquid chromatography to contain four components with $M_{\mathrm{r}}$ values ranging from 100000 to $<20000$.

\section{Radioimmunoassay}

Serial dilutions of fractions A, B, C and D were parallel with the bovine GH standard (NIH-GHB2; 1.5 units $/ \mathrm{mg}$ ) in a specific radioimmunoassay (Fig. 4). The assay shown is less sensitive than usual, as the pre-incubation step was omitted. None of the peaks contained immunoreactive prolactin when tested in the radioimmunoassay at concentrations up to $12.8 \mu \mathrm{g} / \mathrm{ml}$.
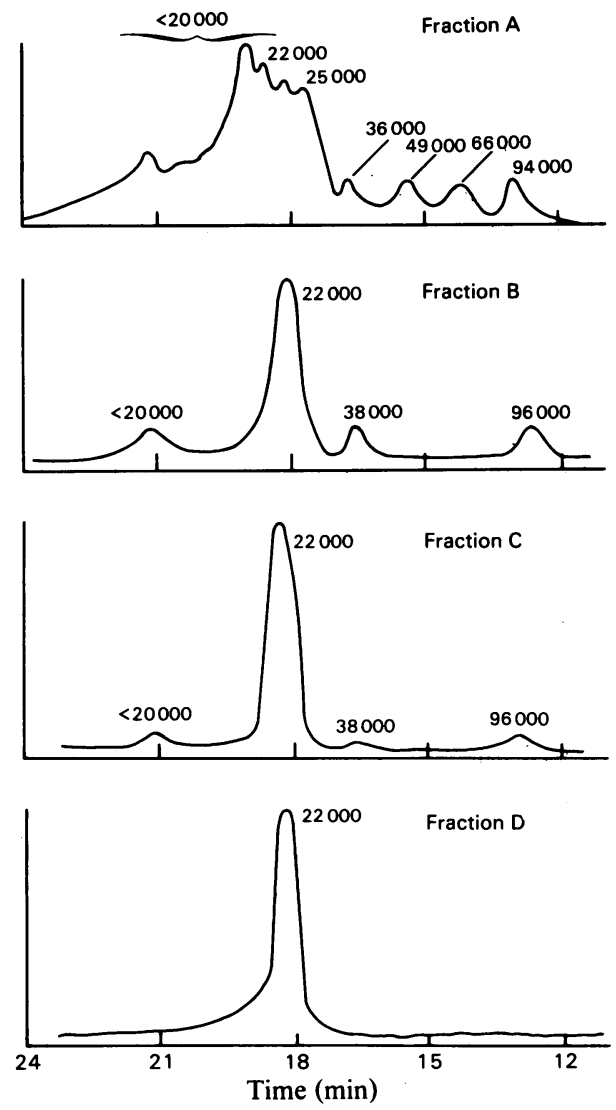

Fig. 3. Approximate $M_{r}$ values obtained by high-pressure liquid chromatography

High-pressure liquid-chromatographic separation was achieved with an Ultropac column (TSK 93000 $\mathrm{SW} ; 7.5 \mathrm{~mm} \times 600 \mathrm{~mm}$ ) and eluted with $0.1 \mathrm{M}$-potassium phosphate buffer $\mathrm{pH} 7.5$, at a flow rate of $0.75 \mathrm{ml} / \mathrm{min} . M_{\mathrm{r}}$ values are marked on the Figure. 


\section{Growth-promoting activity}

Growth-promoting activity tended to increase from fractions $A$ to $D$ (Table 1). The activity of fraction $A$ was low, and the variation between measurements precluded an accurate determination of potency. The relative potencies of the fractions, calculated from the radioimmunoassay inhibition curves (Fig. 4), are given in Table 1 for comparison. Although there was agreement between the bioassay and the radioimmunoassay

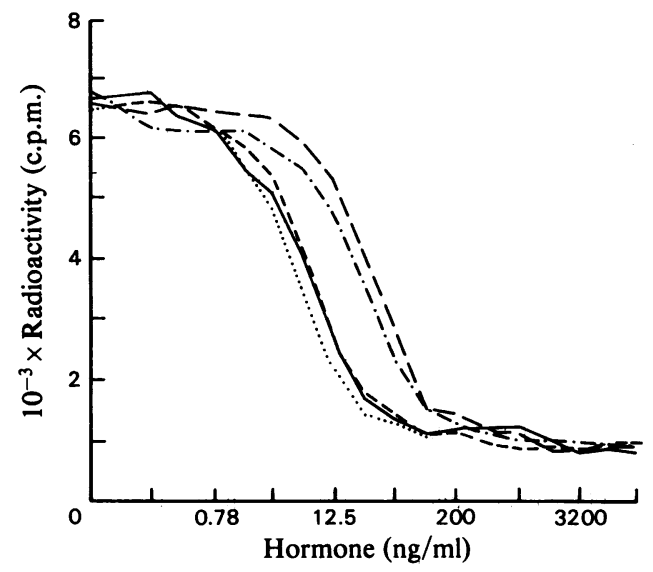

Fig. 4. Binding-displacement characteristics in the radioimmunoassay for ruminant GH (Hart et al., 1975)

...... Bovine GH (NIH-GH-B2; 1.5 units/mg);

- - , fraction $\mathrm{A}$; ----, fraction $\mathrm{B}$; - _, fraction

C; --.---, fraction D. values for fractions $B$ and $C$, there was clearly a discrepancy between the high potency value obtained by the rat tibia test for fraction $\mathrm{D}$ and the low value measured by radioimmunoassay.

\section{Lipolytic activity}

Table 2 lists the lipolytic activity of fractions AD compared with adrenaline $(2 \mu \mathrm{M})$ and with bovine GH (NIH-GH-B15; 0.69 units/mg) prepared by a salt precipitation technique. Since glycerol is not readily metabolized by rat adipose tissue, its release can be taken as a reliable indication of the lipolytic activity of the material tested (Vaughan, 1962). All the preparations significantly increased glycerol production in the presence of dexamethasone over a $4 \mathrm{~h}$ period. The lipolytic activities of fractions A-D were of the same order as that of bovine $\mathrm{GH}$, but all were less active than adrenaline at the dosage tested. There was a tendency for the lipolytic activity to increase from fraction $A$ to fraction $D$, but the additional glycerol produced by fraction $D$ was not significantly greater than that stimulated by fraction $\mathrm{A}$.

\section{Diabetogenic activity}

(a) Glucose transport. Fig. 5 demonstrates that there was no significant difference in basal glucose transport in the epididymal fat of hypophysectomized rats pretreated with saline or fractions $A$ and $D$. However, subcutaneous injection of bovine GH (NIH-GH-B18) and fractions B and $\mathrm{C}$ lowered the rate of 3-O-methylglucose efflux as compared with the controls. At each time

Table 1. Growth-promoting and immunological activities of fractions $A-D$ as measured by the rat tibia test and radioimmunoassay

Radioimmunoassay values were measured against bovine GH (NIH-GH-B2; 1.5 units/mg; Fig. 2). The method of Greenspan et al. (1949) as modified by $\mathrm{Li}(1977)$ was employed for the rat tibia test. Index of precision for the rat tibia test was 0.46 .

\begin{tabular}{|c|c|c|c|c|c|}
\hline & \multirow{2}{*}{$\begin{array}{c}\text { Dose } \\
\text { ( } \mu \mathrm{g} / 4 \text { days })\end{array}$} & \multirow[b]{2}{*}{$\begin{array}{l}\text { No. of } \\
\text { rats }\end{array}$} & \multirow{2}{*}{$\begin{array}{l}\text { Width of tibial } \\
\text { cartilage }(\mu \mathrm{m})^{*}\end{array}$} & \multicolumn{2}{|c|}{ Potency (units/mg) $†$} \\
\hline & & & & Rat tibia test & Radioimmunoassay \\
\hline Bovine GH (NIH-GH-B15) & $\begin{array}{c}\text { Control } \\
20 \\
80 \\
320\end{array}$ & $\begin{array}{r}10 \\
10 \\
12 \\
9\end{array}$ & $\begin{array}{r}76 \pm 3.4 \\
114 \pm 4.3 \\
181 \pm 4.9 \\
269 \pm 5.2\end{array}$ & & \\
\hline Fraction A & $\begin{array}{r}40 \\
160\end{array}$ & $\begin{array}{l}8 \\
7\end{array}$ & $\begin{array}{c}82 \pm 7.6 \\
114 \pm 11.4\end{array}$ & Low & $0.25(0.19-0.35)$ \\
\hline Fraction B & $\begin{array}{r}40 \\
160\end{array}$ & $\begin{array}{l}8 \\
8\end{array}$ & $\begin{array}{l}156 \pm 4.7 \\
255 \pm 5.6\end{array}$ & $0.86(0.59-1.31)$ & $0.97(0.81-1.28)$ \\
\hline Fraction $\mathrm{C}$ & $\begin{array}{l}20 \\
80\end{array}$ & $\begin{array}{l}7 \\
8\end{array}$ & $\begin{array}{l}140 \pm 4.3 \\
210 \pm 6.1\end{array}$ & $1.29(0.94-1.85)$ & $1.00(0.84-1.33)$ \\
\hline Fraction D & $\begin{array}{l}20 \\
80\end{array}$ & $\begin{array}{l}7 \\
7\end{array}$ & $\begin{array}{l}150 \pm 5.1 \\
222 \pm 4.0\end{array}$ & $1.51(1.01-2.01)$ & $0.29(0.24-0.37)$ \\
\hline
\end{tabular}

* Means \pm s.E.M.

+ Numbers in parentheses refer to $95 \%$ fiducial limits of potency.

Vol. 218 
Table 2. Effect of bovine $G H$, adrenaline and fractions $A-D$ on the release of glycerol from rat epididymal fat in vitro Rat epididymal fat was incubated for $4 \mathrm{~h}\left(37^{\circ} \mathrm{C}\right)$ with either buffer (control) or the material to be tested in the presence of dexamethasone $(0.2 \mu \mathrm{g} / \mathrm{ml})$. Glycerol was analysed by the Boehringer fully enzymic method $(n=5 \mathrm{rats} /$ treatment).

\begin{tabular}{|c|c|c|c|c|c|}
\hline \multirow[b]{2}{*}{ Fraction } & \multirow{2}{*}{$\begin{array}{l}\text { Concn. in } \\
\text { medium }\end{array}$} & \multicolumn{2}{|c|}{$\begin{array}{l}\text { Glycerol release } \\
(\mu \mathrm{mol} / 4 \mathrm{~h} \text { per } \mathrm{g})^{*}\end{array}$} & \multirow{2}{*}{$\begin{array}{c}\text { Increase above } \\
\text { control }(\%)\end{array}$} & \multirow[b]{2}{*}{$P \dagger$} \\
\hline & & Control & Treatment & & \\
\hline Adrenaline & $2 \mu \mathrm{M}$ & $3.4 \pm 0.52$ & $9.7 \pm 0.40$ & 185.3 & $<0.001$ \\
\hline Bovine GH (NIH-GH-B15) & $0.1 \mathrm{mg} / \mathrm{ml}$ & $4.6 \pm 0.35$ & $8.7 \pm 0.70$ & 89.1 & $<0.01$ \\
\hline Fraction A & $0.1 \mathrm{mg} / \mathrm{ml}$ & $5.4 \pm 0.18$ & $8.9 \pm 1.11$ & 64.8 & $<0.01$ \\
\hline Fraction B & $0.1 \mathrm{mg} / \mathrm{ml}$ & $4.6+0.70$ & $8.5+0.81$ & 84.7 & $<0.01$ \\
\hline Fraction C & $0.1 \mathrm{mg} / \mathrm{ml}$ & $4.7 \pm 0.62$ & $9.4 \pm 0.61$ & 100.0 & $<0.001$ \\
\hline Fraction D & $0.1 \mathrm{mg} / \mathrm{ml}$ & $3.5 \pm 0.48$ & $7.3 \pm 0.52$ & 108.5 & $<0.01$ \\
\hline
\end{tabular}

* Means \pm S.E.M.

† Comparison of treatment with control.

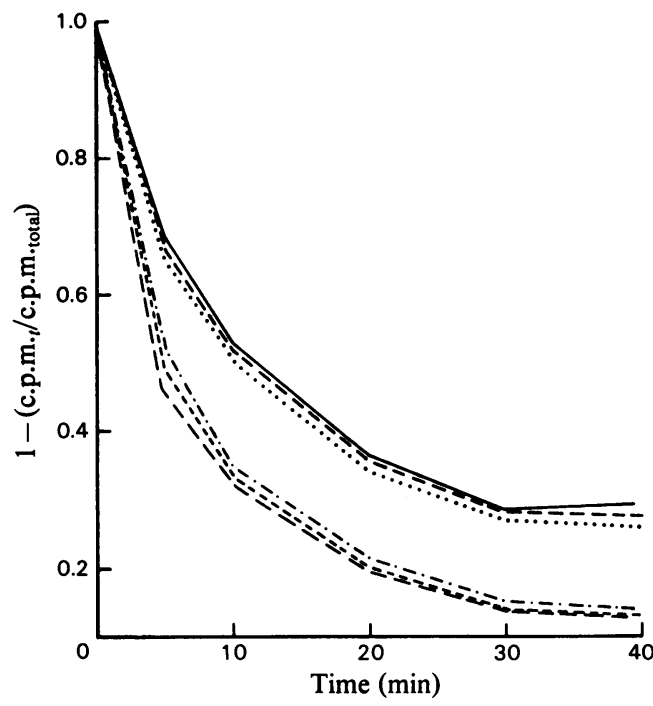

Fig. 5. Glucose transport in fat from hypophysectomized rats

Hypophysectomized male rats were pretreated for 3 days $(100 \mu \mathrm{g} / 0.2 \mathrm{ml}$ per day) with bovine $\mathrm{GH}$ (NIH-GH-B18; 0.81 unit/mg; $\cdots \cdot . \cdot$ ), fraction A (- -), fraction B (---), fraction C (-), fraction $\mathrm{D}(-\cdot-\cdot-)$ or $0.9 \% \mathrm{NaCl}(-\cdot-\cdot-)$ $(n=5)$. The epididymal fat was loaded with 3-O-[U-14 $\left.{ }^{14}\right]$ methylglucose and the rate of efflux was measured throughout a $40 \mathrm{~min}$ period.

interval the efflux for each of these treatments was significantly less than that of the controls at $P$ levels of $<0.05$ by the paired $t$-test.

(b) Insulin-tolerance test. Preparations that lowered the rate of glucose transport in adipose tissue from hypophysectomized rats also caused a marked decrease in insulin-sensitivity at the dosages tested (Fig. 6). Pretreatment with bovine
GH and fractions $\mathrm{B}$ and $\mathrm{C}$ significantly diminished the fall in plasma glucose concentration that occurred after insulin injection in the salinetreated controls. When the goats were treated with fractions $A$ and $D$, the post-insulin fall in glucose concentration was similar to that found after the control period.

\section{Discussion}

The present results lend further support to the concept, based largely on work with the human hormone, that $\mathrm{GH}$, as commonly extracted, is a mixture of different molecular forms and that the different properties of these forms might explain the multiple metabolic activities of the hormone (Lewis et al., 1980).

The $A_{280}$ profiles resulting from chromatography of the bovine anterior-pituitary extracts were similar to those obtained by Wallis \& Dixon (1966). However, the use of DEAE-Sephacel instead of DEAE-cellulose clearly improved the separation and made it easier to distinguish the four protein peaks.

The results from sodium dodecyl sulphate/polyacrylamide-gel electrophoresis and high-pressure liquid chromatography agreed in some respects but not in others. Both techniques indicated that fraction A was markedly heterogeneous in comparison with the other three fractions and that fractions B and $\mathrm{C}$ contained proteins of similar $M_{\mathrm{r}}$ values. Although the $22000-M_{\mathrm{r}}$ component was present in all of the fractions, the methods did not agree with respect to the $M_{\mathrm{r}}$ values of the other components in each of the four preparations. We have no explanation for these differences beyond the possibility that the same proteins migrated at different rates in the two systems or that the different conditions of analysis caused some of the proteins to dissociate or aggregate. It seems likely that the 


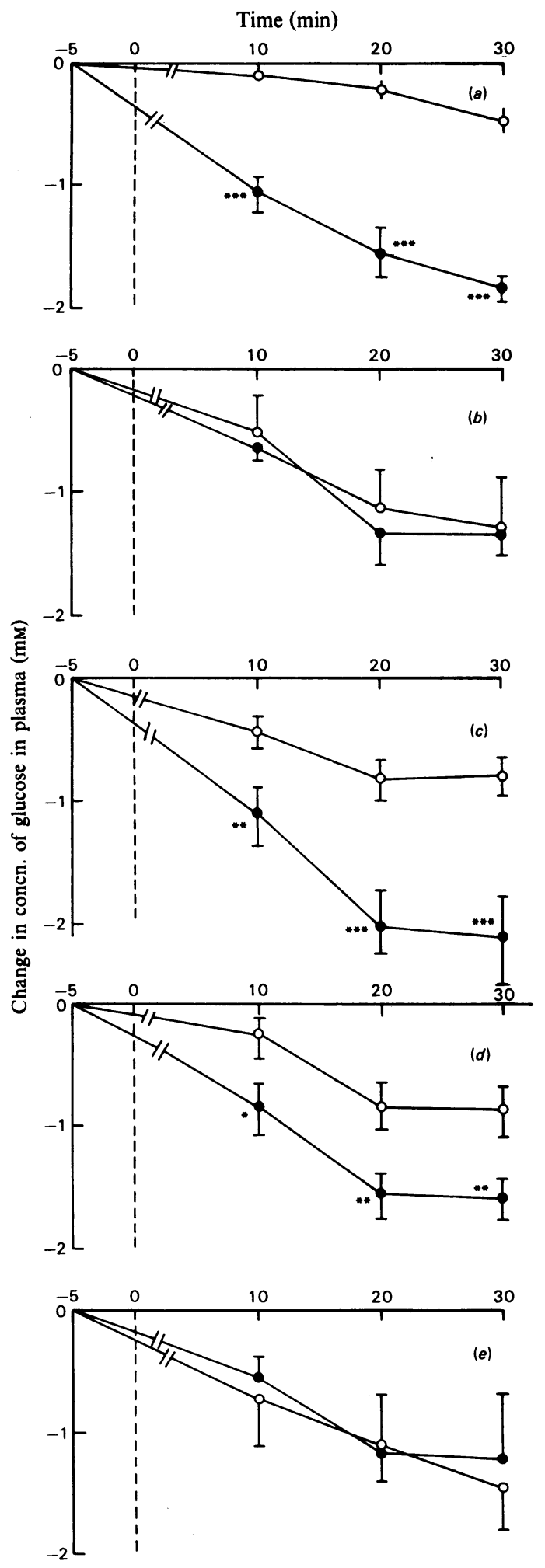

Fig. 6. Intravenous insulin-tolerance tests in goats Tolerance tests towards intravenous insulin $(0.08$ unit $/ \mathrm{kg}$ ) were conducted in goats both before and additional components found in two preparations of fraction D were due to incomplete chromatographic separation of fraction D from the other material. More-limited studies with the use of conventional polyacrylamide-gel electrophoresis and polyacrylamide-gel isoelectric focusing also supported the conclusion that fraction $D$ was the most homogeneous (I. C. Hart \& S. James, unpublished work).

Parallel inhibition curves were obtained in the radioimmunoassay for ruminant $\mathrm{GH}$ and thereby indicated that all of the fractions contained immunoreactive bovine $\mathrm{GH}$, and, when compared on a weight basis, fractions $B$ and $C$ contained the most-immunoreactive material. The absence of immunoreactive prolactin is significant both in terms of the diabetogenic activity of the material (see below) and because most preparations of sheep and bovine GH obtained by salt precipitation contain 1-5\% immunoreactive prolactin (Hart, 1972; I. C. Hart, unpublished work). Thus use of this chromatographic procedure for extracting bovine $\mathrm{GH}$ yields products that are free of this major hormonal contaminant.

Results from the rat tibia test agreed with those obtained by measuring the weight gain of hypophysectomized rats (Wallis \& Dixon, 1966), in that both bioassays detected a tendency for growthpromoting activity to increase from fractions A through to $\mathrm{D}$. Others have used crude bovine $\mathrm{GH}$ to prepare fractions that differ in growth-promoting activity (Manchester \& Wallis, 1963; Dellacha \& Sonenberg, 1964).

The discrepancy between the potency values calculated for fraction $D$ from the rat tibia test and the radioimmunoassay was consistent for all preparations examined, and was of interest as this was the most homogeneous material. Experiments in rats have shown that there was good agreement between bioassay and radioimmunoassay estimates of GH potency when the pituitaries were obtained during a resting state of hormone secretion, but this relationship disappeared when the hormone was measured in pituitaries stimulated to secrete GH (Daughaday et al., 1968; Müller et al., 1970). Similar discrepancies between bioassayable and radioimmunoassayable GH have been found

after subcutaneous injection $(0.15 \mathrm{mg} / \mathrm{kg}$, twice daily) of (a) bovine GH (NIH-GH-B 18; 0.81 unit $/ \mathrm{mg}$ ), (b) fraction $A,(c)$ fraction $B,(d)$ fraction $C$ and $(e)$ fraction $D(n=3)$. Values are changes in plasma glucose concentrations ( \pm S.E.M.). Statistics refer to a comparison of mean values at each time interval for the experimental treatment $(O)$ and control (O). Statistical significance of difference: ${ }^{*} P<0.05 ;{ }^{* *} P<0.01 ;{ }^{* *} P<0.001$. 
by others, and have prompted the suggestion that, after suitable stimulation, rat GH may be modified, before or after secretion, to a form that either retains or has enhanced growth-promoting activity but is not identified by antibodies raised against the purified pituitary hormone (Singh et al., 1974; Vodian \& Nicoll, 1976, 1977; Ellis et al., 1978). The divergent results obtained by radioimmunoassay and bioassay for fraction $D$ suggest that a similar situation might exist for the bovine hormone.

Extraction and fractionation of pituitary extracts on DEAE-Sephacel failed to produce bovine GH that lacked lipolytic activity. The activity of each fraction was comparable with that of bovine GH produced by the method of Ellis (1961). It is unlikely that the lipolytic activity of the fractions was due to contamination with thyrotropin (Rao \& Ramachandran, 1977), as recent administration of these materials to goats $(10-20 \mathrm{mg}$, subcutaneously and intravenously) did not raise the plasma triiodothyronine concentration over a $36 \mathrm{~h}$ period (I. C. Hart, unpublished work). Furthermore, the extraction and fractionation of sheep and human GH by a similar technique yielded a product containing negligible quantities of other anteriorpituitary hormones (Wallace \& Ferguson, 1963; Lumley-Jones et al., 1979).

Evidence is accumulating that suggests that the so-called intrinsic lipolytic activity of $\mathrm{GH}$ may be due to contamination with either a small- $M_{\mathrm{r}}$ protein or a cleaved form of GH (Salaman, 1972; Assa \& Laron, 1977; Schleyer \& Voigt, 1977; Frigeri, 1980; Frigeri et al., 1982). Although the markedly heterogeneous fraction A possessed both low growth-promoting and radioimmunoassay activity, its lipolytic activity was similar to that of crude bovine GH and the other fractions. If it is assumed that growth-promoting activity is a property of the pure monomer, this finding tends to support the argument that the lipolytic activity is not an intrinsic property of the molecule.

Measurement of glucose transport by the method of Zapf et al. (1981) afforded a rapid evaluation of diabetogenic activity, which was confirmed by the insulin-tolerance test in goats, a species that possesses a form of $\mathrm{GH}$ immunologically similar to that of cattle (Hart et al., 1975). The inhibitory influence of bovine $\mathrm{GH}$ (NIH-GH-B18) on glucose transport substantiates the work of others, and reinforces the contention that the semi-purified hormone exerts its diabetogenic influence by antagonizing the stimulatory effect of insulin, possibly at a post-receptor site (Schoenle et al., 1981, 1982; MacGorman et al., 1981).

The potency of fraction $D$ in the tibia test in the absence of diabetogenic activity supports the theory that the latter is a property of either a modified form or fragment of $\mathrm{GH}$ or some other contaminant. Raben \& Westermeyer (1952) were among the first to suggest that pig $\mathrm{GH}$ could be prepared without diabetogenic activity, and more recently Lewis and co-workers have discovered that more-homogeneous preparations of human GH are not diabetogenic. They have partially purified a diabetogenic component from crude human GH and claim that this has an $M_{\mathrm{r}}$ value of less than 5000 (Lewis et al., 1977, 1980; Singh et al., 1982). Furthermore, they were able to convert nondiabetogenic human $\mathrm{GH}$ into a diabetogenic form by proteolytic modification, thereby suggesting that the active material is a modified form of $\mathrm{GH}$, a contention supported by the fact that short sequences of human GH have been found to be diabetogenic in rats and rabbits (Lostroh \& $\mathrm{Krahl}$, 1976; Bornstein, 1978).

However, the diabetogenic activity of the bovine anterior pituitary is not necessarily the exclusive property of $\mathrm{GH}$-related compounds. In 1966 a polypeptide was extracted and found to be diabetogenic in man and dogs (Louis et al., 1966). This material was named bovine diabetogenic peptide and possessed neither growth-promoting activity (Tutwiler \& Louis, 1971) nor lactogenic activity (Louis \& Conn, 1968). However, evidence is gradually accumulating to suggest this material is closely related to prolactin. The lack of lactogenic activity has been disputed (Tutwiler, 1976), and the physical and chemical properties of bovine diabetogenic peptide and prolactin were very similar (Rogol et al., 1978). Furthermore, we have examined a highly purified preparation of bovine diabetogenic peptide (kindly supplied by Professor L. H. Louis) in the prolactin radioimmunoassay and found a complete cross-reaction with an immunological potency similar to that of the bovine prolactin standard (NIH-P-B2; I. C. Hart, unpublished work). Whatever the conclusions to be drawn from this, the complete absence of immunological prolactin in fractions A-D suggests that none of these materials contained bovine diabetogenic peptide.

\footnotetext{
Were are indebted to Dr. P. Andrews, Dr. T. Andrews and Mr. S. James for chromatographic and analytical advice, to Miss Michèle Cleveland, Mrs. Lorraine Newman, Miss Victoria Ashton and Mrs. Jasmine Barley for technical assistance and the staff of the Small Animal Unit and Goat House for care of the animals. We are grateful to the National Institute of Arthritis, Metabolism and Digestive Diseases, National Institute of Health, Bethesda, MD, U.S.A., for supplies of bovine prolactin and $\mathrm{GH}$ used in the radioimmunoassays.
} 


\section{References}

Assa, S. \& Laron, Z. (1977) Horm. Metab. Res. 9, 294-299

Bornstein, J. (1978) Trends Biochem. Sci. 3, 83-85

Daughaday, W. H., Peake, G. T., Birge, C. A. \& Mariz, T. K. (1968) Excerpta Med. Int. Congr. Ser. 158, 238252

Dellacha, J. M. \& Sonenberg, M. (1964) J. Biol. Chem. 239, 1515-1520

Clausen, T. (1969) Biochim. Biophys. Acta 183, 625-634

Cowie, A. T., Forsyth, I. A. \& Hart, I. C. (1980) Hormonal Control of Lactation, Springer-Verlag, Berlin, Heidelberg and New York

Ellis, S. (1961) Endocrinology (Baltimore) 69, 554-562

Ellis, S., Vodian, M. A. \& Grindeland, R. E. (1978) Recent Prog. Horm. Res. 34, 213-238

Frigeri, L. G. (1980) Endocrinology (Baltimore) 107, 738743

Frigeri, L. G., Robel, G. \& Stebbing, N. (1982) Biochem. Biophys. Res. Commun. 104, 1041-1046

Gay, V. L. (1967) Endocrinology (Baltimore) 81, 1177 1179

Greenspan, F. S., Li, C. H., Simpson, M. E. \& Evans, H. M. (1949) Endocrinology (Baltimore) 45, 455-463

Hart, I. C. (1972) J. Endocrinol. 55, 51-62

Hart, I. C. (1983) Proc. Nutr. Soc. 42, 181-194

Hart, I. C., Flux, D. S., Andrews, P. \& McNeilly, A. S. (1975) Horm. Metab. Res. 7, 35-40

Hart, I. C., Bines, J. A., Morant, S. V. \& Ridley, J. L. (1978) J. Endocrinol. 77, 333-345

Lewis, U. J., Singh, R. N. P., Vanderlaan, W. P. \& Tutwiler, G. F. (1977) Endocrinology (Baltimore) 101, 1587-1603

Lewis, U. J., Singh, R. N. P., Tutwiler, G. F., Sigel, M. B., Vanderlaan, E. F. \& Vanderlaan, W. P. (1980) Recent Prog. Horm. Res. 36, 455-508

Li, C. H. (1977) Horm. Proteins Pept. 4, 1-41

Lostroh, A. J. \& Krahl, M. E. (1976) Proc. Natl. Acad. Sci. U.S.A. 73, 4706-4710

Louis, L. H. \& Conn, J. W. (1968) Metab. Clin. Exp. 17, 475-484

Louis, L. H., Conn, J. W. \& Minick, M. C. (1966) Metab. Clin. Exp. 15, 308-324

Lumley-Jones, R., Benker, G., Salacinski, P. R., Lloyd, T. J. \& Lowry, P. J. (1979) J. Endocrinol. 82, 7786

MacGorman, L. R., Rizza, R. A. \& Gerich, J. E. (1981) J. Clin. Endocrinol. Metab. 53, 556-559
Manchester, K. L. \& Wallis, M. (1963) Nature (London) 200, 888-889

Müller, E. E., Giustina, G., Miedico, D., Pecile, A., Cocchi, D. \& King, F. W. (1970) Proc. Soc. Exp. Biol. Med. 135, 934-939

Paul, J. (1965) Cell and Tissue Culture, E. and S. Livingstone, Edinburgh and London

Raben, M. S. \& Westermeyer, V. W. (1952) Proc. Soc. Exp. Biol. Med. 80, 83-85

Rao, A. J. \& Ramachandran, J. (1977) Horm. Proteins Pept. 4, 43-60

Rogol, A. D., Grisson, F. \& Follows, R. E. (1978) Horm. Metab. Res. 10, 515-520

Salaman, M. R. (1972) J. Endocrinol. 55, 459-460

Schleyer, M. \& Voigt, K. H. (1977) Hoppe-Seyler's Z. Physiol. Chem. 358, 1557-1564

Schoenle, E., Zapf, J. \& Froesch, E. R. (1981) Endocrinology (Baltimore) 109, 561-566

Schoenle, E., Zapf, J. \& Froesch, E. R. (1982) Am. J. Physiol. 242, E368-E372

Shapiro, A. L., Viñuela, E. \& Maizel, J. V. (1967) Biochem. Biophys. Res. Commun. 28, 815-820

Singh, R. N. P., Seavey, B. K., Rice, V. P., Lindsey, T. T. \& Lewis, U. J. (1974) Endocrinology (Baltimore) 94, 883-891

Singh, R. N. P., Lewis, L. J., O'Brien, R., Lewis, U. J. \& Tutwiler, G. F. (1982) Program Abstr. Annu. Meet. Endocrine Soc. 64th in the press

Swislocki, N. I., Sonenberg, M. \& Kikutani, M. (1971) Biochem. J. 122, 633-640

Tindal, J. S., Blake, L. A., Simmonds, A. D., Hart, I. C. \& Mizuno, H. (1982) Horm. Metab. Res. 14, 425-429

Tutwiler, G. F. (1976) Acta Diabetol. Lat. 13, 177-185

Tutwiler, G. F. \& Louis, L. H. (1971) Int. J. Biochem. 2, 319-323

Vaughan, M. (1962) J. Biol. Chem. 273, 3354-3362

Vodian, M. A. \& Nicoll, C. S. (1976) Fed. Proc. Fed. Am. Soc. Exp. Biol. 35, 783

Vodian, M. A. \& Nicoll, C. S. (1977) Acta Endocrinol. (Copenhagen) 86, 71-80

Wallace, A. L. C. \& Ferguson, K. A. (1963) J. Endocrinol. 26, 259-263

Wallis, M. \& Dixon, H. B. F. (1966) Biochem. J. 100, 593-600

Weber, K. \& Osborn, M. (1969) J. Biol. Chem. 244, 44064412

Zapf, J., Waldvogel, M., Schoenle, E. \& Froesch, E. R. (1981) FEBS Lett. 135, 199-202 